\title{
MEKANISME INHIBISI ENZIM POLIFENOL OKSIDASE PADA SARI BUAH MARKISA DENGAN SISTEIN DAN ASAM ASKORBAT ${ }^{1}$
}

\author{
Elida Mardiah \\ Laboratorium Biokimia Jurusan Kimia FMIPA Unand
}

\begin{abstract}
The mechanism of polyphenol oxidase enzyme inhibition was studied by isolation of enzyme from the passion fruite juice (Passiflora Sp). The extracted enzyme polyphenol oxidase has an optimum activity at $\mathrm{pH} 5,6$ and temperature of $30^{\circ} \mathrm{C}$ using a pirogalol substrate. The pattern of inhibition of the enzyme polifenol oxsidase studied using cysteine and ascorbic acid. Cystein of $10 \mathrm{mM}$ consentration can inhibit the enzyme polyphenol oxidase activity as $97.25 \%$, ascorbic acid with the same concentration can inhibit the enzyme polyphenol oxsidace $96.5 \%$. The pattern of inhibition of cysteine is more likely to be competitive, while non-competitive with ascorbic acid.
\end{abstract}

Keyword: polyphenol oxsidase, inhibition, cysteine, ascorbic acid

\section{PENDAHULUAN}

Polifenol oksidase (PPO) EC 1.14.18.1 adalah suatu enzim yang termasuk pada golongan oksidoreduktase yang mengkatalisis proses hidrosilasi senyawa monofenol menjadi senyawa difenol, kemudian dilanjutkan dengan mengkatalisis proses oksidasi difenol menjadi kuinon. Senyawa kuinon yang terbentuk sangat reaktif sehingga akan mengalami reaksi polimerisasi menghasilkan pigmen merah, coklat dan hitam yang disebut pigmen melanin. Kesemuanya ini menampakkan warna kecoklatan pada jaringan buah-buahan dan sayur-sayuran yang memar ${ }^{[1]}$.

Pada sel tumbuhan, enzim ini terdapat di dalam vakuola sel dan letaknya terpisah dengan senyawa-senyawa fenol yang terdapat dalam tumbuhan tersebut. Inilah sebabnya reaksi pencoklatan akan terjadi hanya jika jaringan atau selnya rusak. Fungsi dari enzim PPO ini dalam sel yang utuh belum diketahui secara pasti, diperkirakan enzim ini berfungsi sebagai pemacu biosintesis lignin atau berpartisipasi dalam perlindungan mekanik dari jaringan tumbuhan yang luka atau memar ${ }^{[2]}$.

Pencoklatan enzimatik pada buah dan sayuran dalam proses pengolahan merupakan masalah yang serius, karena bagian yang terkelupas dan dipotong akan cepat menjadi gelap warnanya ketika terkena udara. Hal ini tidak diingini karena menampilkan warna serta rupa yang tida bagus dan diiringi rasa yang tidak enak. Proses pencoklatan yang terjadi akan mengurangi kualitas produk dan menurunkan minat konsumen ${ }^{[2,3]}$.

Reaksi pencoklatan enzimatik pada buah dan sayuran dapat diatasi dengan menghinhibisi enzim PPO. Penginhibisi ini harus memperhatikan hal-hal yang dapat mempengaruhi rasa, keamanan dan nilai ekonomisnya. Cara-cara yang pernah dipakai untuk menginhibisi reaksi enzimatik ini antara lain dengan memanaskan, mengurangi kontak dengan oksigen serta penggunaan senyawasenyawa kimia.

Peristiwa pencoklatan akibat oksidasi oleh enzim PPO ini juga terjadi pada buah markisa (Passiflora Sp). Buah markisa selain enak dimakan segar, juga banyak dikonsumsi dalam bentuk sari buah. Enzim PPO yang ada pada sari buah mengakibatkan warna yang dihasilkan kurang menarik (kuning kusam) selain perubahan cita rasanya. Hal ini mengakibatkan rendahnya mutu sari buah markisa serta kurang menarik bagi konsumen. Untuk mengatasi hal tersebut pada percobaan ini digunakan senyawa kimia seperti asam askorbat dan sistein untuk menghambat daya katalitik enzim PPO sari buah markisa ${ }^{[3,5,6]}$. 
Mekanisme reaksi inhibisi enzim PPO sari buah markisa dengan menggunakan inhibitor asam askorbat, dan sisitein belum jelas. Secara umum meknisme inhibisi dapat dibedakan atas inibisi kompetitif, inhibisi nonkompetitif dan inhibisi unkompetitif. Pada jenis inhibisi kompetitif, inhibitor menyebabkan berubahnya harga $\mathrm{Km}$ menjadi lebih besar dari harga $\mathrm{Km}$ semula,sedangkan $\mathrm{V}_{\text {maks }}$ nya tetap. Adanya inhibitor menyebabkan enzim membutuhkan konsentrasi substrat yang lebih besar, untuk mencapai kecepatan maksimum.Inhibisi nonkompetitif, inhibitor menyebabkan turunnya harga $\mathrm{V}_{\text {maks, }}$ tanpa mengubah harga $\mathrm{Km}$ enzim terhadap substrat. Penambahan substrat pada jenis inhibisi nonkompetitif tidak mengurangi hambatan. Secara kinetik inhibisi kompetitif dan inhibisi nonkompetitif dapat dijelaskan dengan mengukur laju kecepatan reaksi pada berbagai konsentrasi substrat dan inhibitror.Pada inhibisi kompetitif titik potong kedua grafik pada sumbu Y,sedangkan pada inihibisi nonkompetitif titik potong kedua grafik pada sumbu X. Inhibisi unkompetitif titik potong kedua grafiknya tidak pada sumbu Y maupun sumbu $\mathrm{X}^{[4,7,8]}$.

\section{METODOLOGI}

\section{Alat-alat}

Alat-alat gelas yang umum dilaboratorium kimia, saringan teh, sentrifuge incubator, $\mathrm{pH}$, meter stirer,spektrofotometer UV-Vis.

\section{Bahan}

Buah markisa (Passiflora $s p$ ) diperoleh dari Pasar Raya Padang, aseton, buffer fosfat, $\mathrm{KCl}$, amonium sulfat, asam askorbat, sistein, pirogalol.

Ekstraksi Enzim PPO dari sari buah Markisa: Buah dikupas dan dikumpulkan isinya lebih kurang $200 \mathrm{~g}$, masukkan dalam saringan teh kemudian gerus dan tampung dengan $100 \mathrm{ml}$ buffer fosfat $0,01 \mathrm{M} \mathrm{pH} 7$ yang ditambah beberapa tetes larutan sistein $0,01 \mathrm{M}$ dalam kondisi suhu rendah. Biarkan satu malam dalam kulkas, kemudian disentrifuge pada 8000 rpm. Selanjutnya supernatan ditambahkan $30 \mathrm{ml}$ larutan $\mathrm{KCl} 1 \%$ distirer selama 30 menit, kemudian disentrifugasi kembali dan diambil supernatannya.

\section{Pemurnian Enzim PPO sari buah Markisa}

Supernatan yang merupakan ekstrak kasar enzim diambil $100 \mathrm{ml}$ ditambahkan aseton dingin secara bertahap sebanyak $100 \mathrm{ml}$ kemudian dibiarkan selama satu malam dan dipisahkan endapan dengan supernatan, endapan diambil dan dilarutkan dalam buffer fosfat $0,01 \mathrm{M} \mathrm{pH} 7$.

\section{Penentuan aktifitas enzim polifenol oksidase}

Aktifitas polifenol oksidase ditentukan dari laju reaksi oksidasi substrat pirogalol dengan adanya polifenol oksidase yang membentuk produk berwarna coklat. Intensitas warna coklat ini diamati dengan spektrofotometer pada panjang $420 \mathrm{~nm}$. Satu unit enzim didefinisikan sebagai kenaikan absorban 0,001 permenit persatuan waktu pada panjang gelombang $420 \mathrm{~nm}^{[4]}$.

\section{Penentuan kondisi optimum aktifitas enzim polifenol oksidase}

Kondisi optimum aktifitas polifenol oksidase dilihat pada suhu $25-40{ }^{\circ} \mathrm{C}$ dan $\mathrm{pH}$ 5- 8 dengan kosentrasi substrat pirogalol $0,5 \mathrm{M}$, yang diamati dengan perubahan aktifitas enzim pada setiap perlakuan yang bervariasi. Aktifitas polifenol oksiadase yang diperoleh identik dengan laju maksimum reaksi pencoklatan $\left(\mathrm{V}_{\mathrm{mak}}\right)$.

\section{Penentuan tingkat dan tipe inhibisi dari masing-masing inhibitor}

Tingkat dan tipe inhibisi dari inhibitor ditentukan dengan cara menambahkan inhibitor dengan konsentrasi bervariasi pada reaksi enzimatik antara polifenol oksidase dengan substrat pirogalol yang juga konsentrasinya bervariasi. Pengujian dilakukan terhadap \% Inhibisi, harga V-maks sebelum dan saat inhibisi, Km ( Konstanta Michelis Menten ) tanpa inhibitor dan dengan inhibitor (Ki). Persentase inhibisi ditentukan pada konsentrasi substrat pirogalol optimum dan kosentrasi inhibitor bervariasi dari $2,5-10$ $\mathrm{mM}$ 


\section{HASIL DAN PEMBAHASAN}

Pemurnian enzim hasil ekstraksi dengan menggunakan aseton kejenuhan 30-60 \% dapat meningkatkan kemurnian enzim sebanyak 2 kali. Pemakaian aseton dengan kejenuhan $50-$ $80 \%$ dapat meningkatkan kemurnian 4 kali. Aktifitas enzim meningkat seiring dengan bertambahnya tahap pemurnian. Ini memperlihatkan konsentrasi enzim dalam larutan makin meningkat.

\section{Pengaruh pH terhadap aktifitas enzim PPO sari buah markisa}

Pengujian aktifitas enzim terhadap perubahan $\mathrm{pH}$ dilakukan pada suhu $27^{\circ} \mathrm{C}$, konsentrasi pirogalol $0,5 \mathrm{mM}$ dengan waktu inkubasi 30 menit.

Tabel 1 . Hasil pengujian aktifitas ekstrak kasar dan beberapa tahap pemurnian

Enzim PPO.

\begin{tabular}{llllll}
\hline $\begin{array}{l}\text { Tahapan } \\
\text { Pemurnian }\end{array}$ & $\begin{array}{l}\text { Vol } \\
(\mathrm{ml})\end{array}$ & $\begin{array}{l}\text { Aktifitas } \\
(\text { Unit/mL) }\end{array}$ & $\begin{array}{l}\text { Protein } \\
(\mathrm{mg} / \mathrm{ml})\end{array}$ & $\begin{array}{l}\text { Aktifitas Spesifik } \\
(\text { Unit/mg })\end{array}$ & $\begin{array}{l}\text { Tingkat } \\
\text { Kemurnian }(\mathrm{X})\end{array}$ \\
\hline Ekstrak Kasar & 200 & 224 & 0,309 & 725 & 1 \\
Aseton $(30-60 \%)$ & 100 & 186 & 0,116 & 1603 & 2 \\
Aseton $(50-80 \%)$ & 150 & 235 & 0,078 & 3012 & 4 \\
\hline
\end{tabular}

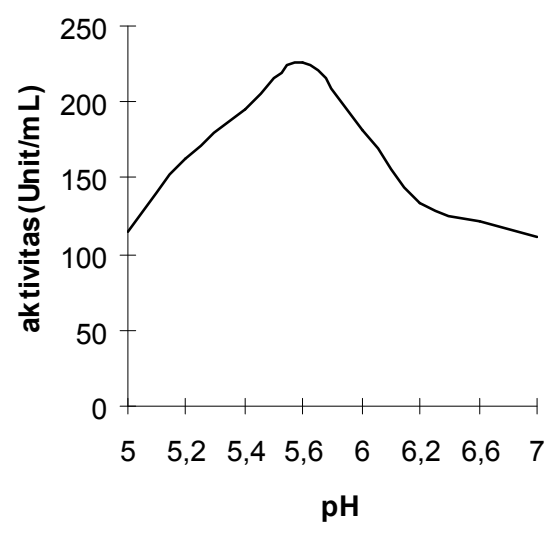

Gambar 1. Kurva pengaruh pH terhadap aktifitas enzim PPO sari buah markisa

Dari Gambar 1, dapat dilihat $\mathrm{pH}$ optimum enzim PPO sari buah markisa untuk substrat pirogalol adalah 5,6. Penurunan aktifitas enzim di atas dan di bawah $\mathrm{pH}$ optimum disebabkan oleh perubahan muatan dari gugus amino enzim. Pada $\mathrm{pH}$ rendah enzim akan terprotonasi sehingga kehilangan mutan negatifnya. Pada $\mathrm{pH}$ tinggi substrat akan terionisasi sehingga kehilangan muatan positifnya. Perubahan muatan inilah yang menyebabkan menurunnya aktifitas enzim.

\section{Pengaruh Suhu terhadap aktifitas Enzim PPO Sari buah markisa}

Setiap enzim mempunyai suhu optimum yang spesifik yaitu suhu dimana aktivitas enzim maksimum. Dari hasil yang telah didapatkan 
suhu optimum enzim PPO sari buah markisa dengan substrat pirogalol adalah $30^{\circ} \mathrm{C}$.

Perubahan suhu mempengaruhi reaksi enzimatis maupun terhadap stabilitas enzim, afinitas enzim serta kecepatan disosiasi komplek enzim substrat. Dibawah suhu optimum enzim memiliki aktifitas yang rendah, karena belum semua enzim teraktivasi, sedangkan diatas suhu optimum aktifitas enzim menurun karena enzim mengalami denaturasi.

\section{Hasil Pengukuran aktifitas enzim PPO dengan menggunakan inhibitor}

Mekanisme reaksi penghambatan sistein bersifat kompetitif, hal ini ditandai dengan berubahnya harga $\mathrm{Km}$, jika konsentrasi substrat diperbesar. Pada konsentrasi $10 \mathrm{mM}$ sistein mampu menghambat aktifitas polifenol oksidase 97,25\%. Sistein merupakan asam amino yang mempunyai gugus sulfhidril,gugus ini berinteraksi dengan produk 0-quinon membentuk senyawa Cystein Quinon Addition Compound (CQAC), yang mengakibatkan senyawa melanoidin berwarna coklat tidak terbentuk. CQAC mempunyai struktur mirip dengan substrat, sehingga CQAC juga dapat berikatan dengan pusat aktif enzim berkompetisi dengan substrat, sehingga sistein dapat bersifat inhibitor kompetitif. ${ }^{[6]}$ Disamping itu sistein dapat juga menghambat aktifitas enzim polifenol oksidase dengan membentuk komplek yang stabil dengan $\mathrm{Cu}$ yang merupakan kofaktor enzim, sehingga enzim menjadi tidak aktif..$^{[3,6]}$

Mekanisme reaksi penghambatan asam askorbat bersifat non - kompetitif, hal ini ditandai dengan bertambah besarnya konsentrasi substrat harga $\mathrm{Km}$ tidak mengalami perubahan. Asam askorbat mempunyai daya inhibisi 96,5 \% untuk konsentrasi 10,0 mM. Kerja asam askorbat sebagai inhibitor berbeda dengan sistein. Asam askorbat mereduksi kembali o-quinon yang terbentuk menjadi senyawa fenol dimana asam askorbat melepaskan 2 molekul hidrogennya dengan membentuk dehidroasam askorbat. Dengan terbentuknya senyawa fenol kembali maka reaksi lanjutan pembentukan melanin dari quinon tidak berlangung. ${ }^{[9]}$

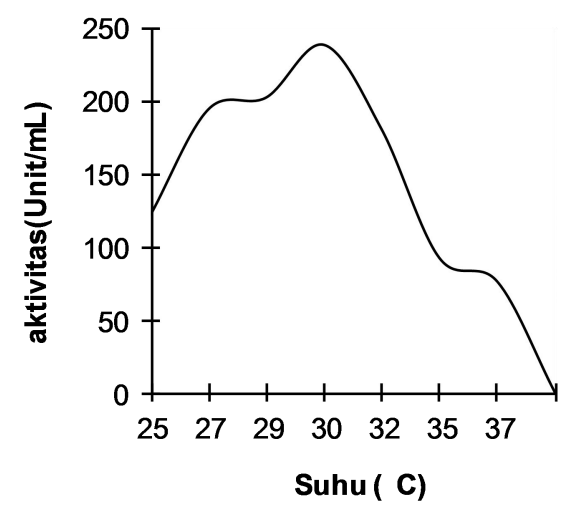

Gambar 2. Kurva pengaruh suhu terhadap aktifitas enzim PPO sari buah markisa 


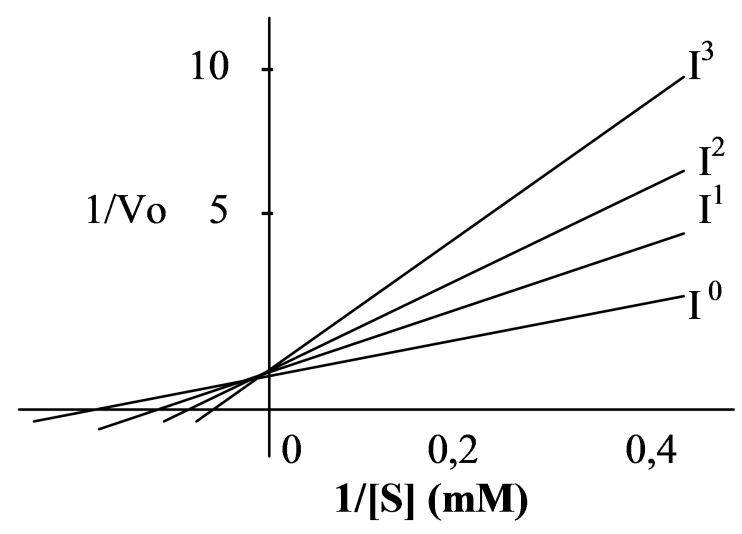

Gambar 3. Kurva inhibisi sistein terhadap aktifitas enzim polifenol oksidase dengan substrat pirogalol Keterangan :

$\mathrm{I}^{0}=$ Konsentrasi sistein $0 \mathrm{~m} \mathrm{M}(\% \mathrm{I}=0 \%)$

$\mathrm{I}^{1}=$ Konsentrasi sistein $2,5 \mathrm{~m} \mathrm{M}(\% \mathrm{I}=32 \%)$

$\mathrm{I}^{2}=$ Konsentrasi sistein $5,0 \mathrm{~m} \mathrm{M}(\% \mathrm{I}=67 \%)$

$\mathrm{I}^{3}=$ Konsentrasi sistein $10,0 \mathrm{~m} \mathrm{M}(\% \mathrm{I}=97,25 \%)$

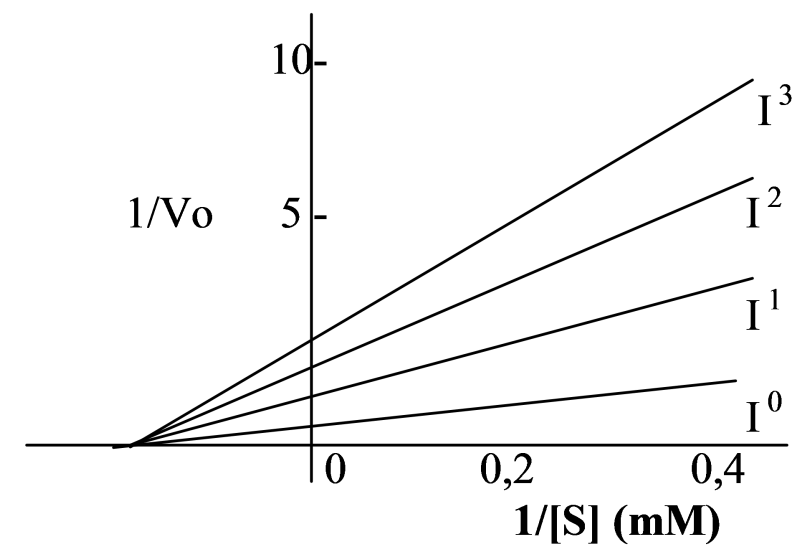

Gambar 4 : Kurva inhibisi asam askorbat terhadap aktifitas enzim polifenol oksidase dengan substrat pirogalol

Keterangan:

$\mathrm{I}^{0}=$ Konsentrasi asam askorbat $0 \mathrm{~m} \mathrm{M} \quad(\% \mathrm{I}=0 \%)$

$\mathrm{I}^{1}=$ Konsentrasi asam askorbat $2,5 \mathrm{~m} \mathrm{M}(\% \mathrm{I}=20 \%)$

$\mathrm{I}^{2}=$ Konsentrasi asam askorbat 5,0 $\mathrm{m} \mathrm{M}(\% \mathrm{I}=67 \%)$

$\mathrm{I}^{3}=$ Konsentrasi asam askorbat 10,0 m M (\% I = 96,5\%)

\section{KESIMPULAN}

Dari hasil penelitian yang telah dilakukan dapat diambil kesimpulan sebagai berikut : 1) Dari sari buah markisa (Passiflora $s p$ ) dapat diekstrak enzim polifenol oksidase, 2) Kondisi optimum dari enzim polifenol oksidase sari buah markisa pada $\mathrm{pH} 5,6$, dan suhu $30^{\circ} \mathrm{C}$ dengan substrat pirogalol, 3) Sistein dengan konsentrasi $10 \mathrm{mM}$ dapat menghambat aktifitas enzim polifenol oksidase sampai 97,25\%., sedangkan asam askorbat dengan konsentrasi yang sama dapat menghambat enzim polifenol oksidase $96,5 \%$, 4) Mekanisme reaksi inhibisi sistein terhadap aktifitas enzim polifenol oksidase adalah kompetitif, sedangkan asam askorbat mekanismenya nonkompetitif

\section{DAFTAR PUSTAKA}

1. A. M. Mayer, Polyphenol Oxidases in Plant Recentprogress, Phitochemistry, 26, 11-20. 
2. J. Klapp, A.H. Ricchard F.C., Inhibition Studies on Apple Polyphenol Oxidase, J.Food Chem, 38: 926 - 931, (1990).

3. Molnar, I. Perl, M. Friedman, Inhibitation of Browning bu Sulfur Amino Acid. 3. Apples and Potates, J. Agric. Food Chem, 38: 1652, (1990).

4. E.J. Lowrenco, Polyphenol Oxidase from Sweet Potato Purification and Properties, J.Agric Food Chem, 40: 2369-2373. (1992).

5. J.R. Chan, Passion Fruit in Tropical and Sub Tropical Fruit, John Willey and Sons Inc, (1978).

6. F. C. Richard Forged, and P.M. Goupy Cystein as inhibition of Enzymatic Browning .2. Kinetic Studies J.Agric Food Chem, 41: 532- 536, (1993).

7. M. Y. Coseteng, C.Y. Lee, Changes in apple polyphenol oxidase and polyphenol concentrations in relation to degree of browning, J.Food Sci 52: 985-989, (1987).

8. S. Kremasha, Studies on Inhibitor Mushroom Polyphenol Oxidase using Chlorogenic Acid as Substrat., J.agric. Food Chem, 41: 526-531, (1993).

9. Eskin, Biochemistry of Foods, Academic Press, New York, 70-83, (1971). 